\title{
Monetary and Fiscal Actions in Macroeconomic Models*
}

\author{
by KEITH M. CARLSON
}

ONTROVERSY persists in macroeconomics. This statement sounds trite and almost immediately prompts the response, "What else is new?" With reference to the "monetarist-fiscalist" controversy, this disinterested attitude is probably on the rise. Professor James Tobin, for example, has written:

"If the monetarists and the neo-Keynesians could agree as to which values of which parameters in which behavior relations imply which policy conclusions, then they could concentrate on the evidence regarding the values of those parameters."

In other words, if there were agreement on a common theoretical apparatus, the controversy about relative roles of monetary and fiscal policies could be reduced to an econometric debate about empirical magnitudes.

There are many who believe that the monetaristfiscalist debate centers on empirical questions. For example, Professor Milton Friedman indicated his "belief that the basic differences among economists are empirical, not theoretical." But Professor Tobin is not willing to accept this characterization of the debate. In fact, Tobin expresses disappointment in Friedman's theoretical framework, citing several cases where Friedman displays inconsistency with his earlier works. ${ }^{3}$

This paper is essentially unchanged from its original form as prepared for the Fourth Antual Konstanzer Conference on Monetary Theory and Policy, Konstanz, West Germany, June 1973. Though not fully reflected in this paper, I since have benefited from conments by Professors John Pippinger, Ronald Sutherland, and Jai-Hoon Yang.

1James Tobin, "Friedman's Theoretical Framework," Journal of Folitical Economy (September/October 1972), p. 852 .

2Milton Friedman, "A Theoretical Framework for Monetary Analysis," Joumal of Political Economy (March/April 1970) p. 234. Many other examples could be cited suggesting that this view is common in the profession. Typical is the following statement by Professor Crouch [Robert L. Crouch, Macroeconomics (New York: Harcourt Brace Jovanovich, 1972), p. viii]: “. . macroeconomists are separated only by the assumptions they make concening price flexibility, money illusion, expectations, and distribution effects. Therefore, to the extent that macroeconomists are divided into factions, they are divided over empirical questions and not the theory."

3Tobin, "Friedman's Theoretical Framework."
Since there is confusion as to the nature of the monetarist-fiscalist controversy, it is not surprising that the debate persists. Until there is at least agreement as to the nature of the controversy, we cannot expect much progress toward resolving the central issues."

Professor Karl Brunner has grouped the central issues of macroeconomics under four topics: the nature of the transmission mechanism, the inherent stability of the economic system, the nature of impulses generating economic income fluctuations, and the approximate separation of allocative and aggregative forces. ${ }^{5}$

The focus of this paper is on the monetarist-fiscalist controversy primarily as it relates to (1) the nature of policy impulses and the business cycle and (2) the nature of the transmission mechanism. As background, the historical development of the controversy is traced, albeit cursorily. Next, the current nature of the controversy is examined in greater detail and the Brunner-Meltzer view of the transmission mechanism is discussed in juxtaposition with the well-known Hicksian model. Alternative views of the transmission mechanism can provide some insights into the issues relevant to the monetarist-fiscalist controversy.

4Several articles have appeared since this paper was first drafted which have attempted to identify the issues in the controversy. One is Axel Leijonhufvud, "Effective Demand Failures," Suedish Joturnal of Economics (March 1973), pp. 2748 , where he argues that the central issue concerns the selfregulatory capabilities of market systems. Another is Robert H. Rasche, "A Comparative Static Analysis of Some Monetarist Propositions," this Review (December 1973), pp. 15-23, where he suggests that the issues revolve on the assumptions about price perceptions by economic units. Professor Rasche concludes that the debate over the relative stability of monetary velocity vs. the attonomous expenditure multiplier has been misdirected. Also see Leonall C. Andersen, "The State of the Monetarist Debate, and the accompanying commentary by Lawrence $\mathrm{R}$. Klein and Karl Brunner, this Review (September 1973), pp. 2-14. Important earlier surveys of the issues are Karl Brunner, "A Survey of Selected Issues in Monetary Theory" Schweizerische Zeitschrift fur Volkswirtschaft und Statistik/(Winter 1971), pp. 1-146, and David I. Fand, "Some Issues in Monetary Economics," this Review (January 1970), pp. 10-27.

"See Karl Brunner's review of Bert G. Hickman, ed, Econm ometric Models of Cyclical Behavior, Journal of Econometric Literature (September 1973), pp. 927-33, and "A Survey of Selected Issues in Monetary Theory." 


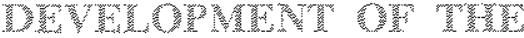

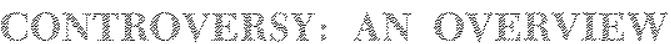

Development of the controversy between monetarists and fiscalists during the post-World War II period is divided into four periods. ${ }^{5}$ Though these periods are not precise and well defined, it is useful to associate evolving opinions and beliefs with the passage of time. Central to the discussion is the interplay of economic experience with economic thinking. Specific economic episodes are capable of having pronounced effects on prevailing macroeconomic thought which rival in importance the effects of carefully prepared theoretical analyses or detailed econometric studies.

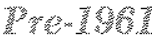

The post-World War II period prior to 1961 can be characterized as the period marking the development of the Keynesian orthodoxy. This orthodoxy centers on the income-expenditure model as the basic analytical framework of macroeconomic analysis. ${ }^{7}$ That is, the " $\mathrm{C}+\mathrm{C}+\mathrm{G}$ " approach tended to dominate macroeconomic thinking, and paralleled closely the development of the national income accounts.

This school of macroeconomic thought developed quite independently of economic experience. For example, during the middle and late 1950 s economic policy involved very little experimentation in efforts to achieve the goals of the Employment Act of 1946. As a result, there were few direct tests of macroeconomic propositions on the economic policy front. As near as economists could tell, monetary and fiscal policies were being conducted on the basis of certain established patterns of behavior, with little interplay between economists and policymakers. ${ }^{8}$ One of the great "missions" of macroeconomists seemed to be

GFor a very readable summary of the development of the controversy, see A. James Meigs, Money Matters: Economics, Markets, Poltics (New York: Harper and Row, 1972), esp. part 4. See also Beryl W. Sprinkel, Money and Markets: A Monetarist View (Homewood, lllinois: Irwin, 1971), esp. pp. $1-17$.

The Keynesian orthodoxy, or tradition, is defined in the sense of Axel Leiionhufvud, on Reynesian Economics and the Economics of Keynes (New Xork: Oxford University Press, 1968). In contrast to Leijonhufvud whose book focuses on specific theoretical issues, the purpose of this section of the paper is to discuss the interplay between economic policy experience and macroeconomic thought in a very general way.

8 For discussion of the role of the economist in the evolution of economic policy in the post-World War II period up to 1961 , see Herbert Stein, The Fiscal Revolution in America (Chicago: University of Chicago Press, 1969), pp. 197-371. See also Hugh $S$. Norton, The Role of the Economist in Government: A Study of Economic Advice Since 1920 (Berkeley: McCutchan Publishing Corporation, 1969). that of convincing policymakers that there were other goals besides balancing the Federal budget. The reasons underlying this lack of interplay between policy and economic thought can be traced to the state of development of economic information at the time and the relatively undeveloped means of processing what information was available. Inability to monitor closely economic conditions contributed to a division between economic thought and policy.

The development of macroeconomic thought prior to 1961 was decidedly Keynesian in the " $\mathrm{C}+\mathrm{I}+\mathrm{G}$ " sense, with little emphasis on monetary policy. The notion of compensatory fiscal policy became a fixture in textbooks long before it was considered at all seriously by policymakers. About the only dissenting voices during this period were those of Clark Warburton and Milton Friedman. Insofar as the Keynesian model and the ascending role for fiscal policy was concemed, this dissenting challenge was not a serious one. Even though the Warburton-Friedman challenge was strongly supported with statistical evidence, the developing Keynesian orthodoxy was not about to backstep to an analysis with classical underpinnings.

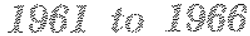

The year 1961 is chosen as the beginning of the next era in macroeconomic thinking primarily because of two significant developments - one dealing with economic policy and the other with a controversial contribution to the economic literature. The policy development was the formation of the "Heller Council," and the "sale" of the Keynesian model to Congress and the public. ${ }^{10}$ A significant development in the literature was the publication of a study on quantity theory vs. Keynesian theory for the Commission on Money and Credit by Professors Friedman and Meiselman. ${ }^{11}$

9The most relevant contributions can be found in Milton Friedman, The Optimum Quantity of Money and Other Essaus (Chicago: Aldine Publishing Company, 1969) and Clark Warburton, Depression, Inflation and Monetary Pol. icies, Selected Papers 1945-53 (Baltimore: Johns Hopkins University Press, 1969). 'There were, of course, others who questioned developing trends in macroeconomic theory duning this period.

10See Stein, The Fiscal Revolution, pp. 372-453. The state of prevailing opinion among macroeconomists as of 1961 is probably best summarized in U.S. Congress, Joint Economic Committee Current Economic Situation and Short-Run Outlook Hearings, 86th Congress, 2nd Session (December 1960), and January 1961 Economic Report of the President and the Economic Situation and Outlook: Hearings, 87th Congress, 1st Session (1961).

11Milton Friedman and David Meiselman, "The Relative Stability of Monetary Velocity and the Investment Multiplier in the United States, 1897-1958," in Commission on 
With reference to applied Keynesian economios, the record and contributions of Professor Walter Heller and his colleagues are familiar. ${ }^{12}$ The notion of "fiscal drag" was developed and eventually Congress was sold on the need for a tax cut to eliminate this "drag." There were few dissenting views within the economics profession during this period of applied Keynesianism. Almost all macroeconomists felt the time was ripe for stimulative policy, and recommendations for expansionary fiscal policy assumed "matterof-factly" that monetary policy was to be accommodative, maintaining stable money market conditions when the Federal Government required funds to finance the deficit. ${ }^{13}$

The 1964 tax cut was considered an unqualified success by most analysts at that time, and the stabilization potential of fiscal policy was enhanced by the acceleration of depreciation allowances and the implementation of an investment tax credit, both in 1962." In fact, by late 1965 the faith in fiscal policy was apparently so strong that it was felt that any significant move toward restraint could be postponed until the last possible moment so as to get maximum advances in output before turning to the problem of checking inflation. ${ }^{15}$

The other development, the Friedman-Meiselman (F-M) study, was creating substantial discussion in academic circles during the 1961 to 1966 period. ${ }^{10}$ The $\mathrm{F}-\mathrm{M}$ study represented a statistical challenge to the Keynesian orthodoxy. The F-M study really did not present evidence which was inconsistent with Keynesian theory, but, rather, the statistical evidence was presented as also being consistent with quantity theory.

Money and Credit, Stabilization Policies (Englewood Cliffs, N.J.: Prentice-Hall, Ine. 1963), pp. 165-266.

12For an informative accounting of the accomplishments of the Heller Council, see Walter W. Heller, New Dimensions of Political Economy (Cambridge, Mass.: Harvard University Press, 1966).

13See any of the Annual Reports of the Council of Economic Advisers from 1962 through 1966.

${ }^{14}$ For an example of one of the few dissenting views at that time, see Allan H. Meltzer, "The Money Managers and the Boorn," Challenge (March/April 1966), pp. 5-7.

15The following quotation is typical: "Consultations between the Federal Reserve and the Administration contime, helping to assure that monetary and fiscal policy together will provide appropriately for sustained and balanced expansion. Both are keenly aware of uncertainty in the outlook and are prepared to respond to emerging developments." The Anntual Report of the Council of Economic Advisers (Washington: U.S, Government Printing Office, 1966), p. 60 .

16For the relevant references, see Ronald L. Teigen "A Critical Look at Monetarist Economics" this Reviete (January 1972), pp. $10-25$
The F-M study prompted a reaction in defense of the Keynesian model, as well as a challenge to the methodology of the F-M study. In general, after the smoke had cleared and scores of words had appeared, both sides emerged believing they had won. ${ }^{17}$ And until 1965 or 1966, Keynesian supporters could cite apparent successes in applied Keynesianism as additional evidence buttressing their position.

Late 1965 could be characterized as a low point for quantity theorists, or more generally for anyone who believed in the potency of monetary actions. ${ }^{18}$ It was not that economic conditions were inconsistent with the tenets of the quantity theory, but rather that fiscal policy appeared to be so successful that monetary policy was cast in a minor supporting role. For example, the 1966 article by Professor Allan Meltzer challenged the success of the 1964 tax cut, but there is no evidence in the literature indicating that Meltzer's challenge was taken seriously.

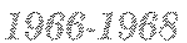

This brief period is noted primarily because of economic events and not the development of economic literature. ${ }^{19}$ Late 1965 and early 1966 marked a significant shift in economic policy. Fiscal policy was stimulative in late 1965. In fact, there was an overt move toward stimulus with an excise tax cut as well as an unplanned stimulus from Vietnam War expenditures. As the fiscal stimulus continued and the economy approached capacity, the Federal Reserve noved independently, announcing a policy of restraint and increasing the discount rate in December 1965. Monetary restraint became effective by spring 1966 when growth in the money stock came to a halt. The result of this combination of stimulative fisoal actions and restrictive monetary actions is well known; in late 1966 the economy slipped into a mini-recession.

17For example, in Teigen, "A Critical Look," p. 10, says, "The empirical evidence presented in support of this cuantity theory' viewpoint was subjected to criticism so severe that the evidence has never been taken very seriously."

${ }_{18}$ Note the following statement from Jeller, New Dimensions, p. 9: "The basic structure of the Keynesian theory of income and employment - and even the basic strategies of Hansenian policy for stable full employment - are now the village common of the economics commurity. When Multon Friedman, the chief guardian of the latssez-fame tralltion in Americant economics, said not long ago, "We are all Keyn nesians now, the profession said 'Amen."

19Given normal publication lags, as well as recognition lags by econonists, it is probably impossible to detect any trends in economic literature for a period as short as two or three years. To gain insights into cconomic thinking on policy issues during short periods, testimony before Congressional Conmitees is probably the best source, rather han the professional journals. 
Within the conomics profession, but chefy among policymakers, the power of monetary restraint was quickly recognized. In fact, ont of fear of a mator recession, monetary actions tumed stmulative in early 1967. The response of the economy was very rapid. In combination with continuing fiscal stimulus, the tum to monetary stimulus very guichy les to a re-emergence of inflation.

This short experience of about two years resulted in a more eclectic view of monetary and fiscal policy among macroeconomists. General belief in the power of fiscal policy continued, but now monetary policy was recognized for its potential contribution. This experience, however, was not viewed as a defeat for fiscal policy and the Keynesian model, Rather, the experience suggested that the economy hat moved into the "classical range" of the $L M$ curve - the range in which monetary actions have their greatest potency relative to fiscal actions.

This shor period from 1966 to early 1968 can be dubbed as the "emergence of eclecticism." Interest in the Friedman-Meiselman controversy waned bectuse that controversy implied that one of two extreme positions should be accepted. The experience of 1966 to 1988, though demonstrating a dominant role for monetary actions, led ro the general conclusion that both monetary and fiscal policy "mattered." The de. velopment of the FRB-MTT model at this time was consistent with such an eclectic position. ${ }^{21}$

\section{Mristion}

The final period of review begins with the implementation of the tax surcharge of 1968, which was also accompanied by legislated controls on Federal spending. Fait in the success of this fiscal action was so great that monetary policy was shifted toward ease to avoid "overkill." Monetary expansion was rapid well into 1969, and inflation accelerated. Accelerating inflation in the face of fiscal restraint was a setback for the advocates of fiscal policy. If monetary restraint could slow the economy in 1966 in the face of fiscal stmulus, why could not the tables be turned? After

20 " $n$ partictlar, the power of thent money as a tool of restraint - as well as its nneven impact - was demonstrated beyond any reasonable doubt," The Ammat Report of the Council of Economic Advisers (Washington: U.S. Gotemment Printing afice, 1967$), p, 38$.

21Frank deleeww and Edward M. Gramlich, "rhe Federal Reserve-MIT Econometric Model," Federal peserve Bulletin (January 1968), pp. 11-40, and "The Channels of Monetary Policy: $A$ Further Report on the Federal Reserve - MTT Econometric Wodel," Federal Reserve Buldotin (June 1969), pp. $472-91$. the fact, the explantation offered by the supporters of Keynesian theory was that the surcharge was viewed by economio wnits as temporary.22 The damage to the "fiscalst position" was especially signifoant because it marked the first poliey setback for Keynesianism singe its serous application began in 1961 .

At about the same time that doubt was beginning to emerge as to the effectiveness of the 1968 tax surcharge, the indersen-Jordan (A-J) shady was published. ts the intial reaction by Keymesians was that the $A-I$ results were simply a rerm of the riedmanMeiselman estimates, except that more sophisticated procedures were used in estinating the lags in the response of economic activity to monetary and fiscal actions. But controversy started bulding up as the success of the 1968 surcharge became more and more suspect.

The A-I resulits were impressive, and to the limited extent that Keynesians attempted to "beat" them at their own game, the $A-1$ results stood up remarkably well ${ }^{25}$ As it became diffoult to connter the A.I results on statistical grounds, the "black box" notion developed.26 That is, the old "correlation is not causation" argument appeared, and Keynesians sad, "Where is your theory?" Such criticism had been lingering mused among the Keynesians for several years, but the new challenge to the Keynesians prowoked a reincamation of the black box.

22Bee Teigen, "A Critical Look" frotrote 4 and the teterences cited theren.

wheonall C. Andersen and Jerry L. Jordan, "Monetary and Fiscal Actions: A Test of Their Relative Importance in Economic Stablization," this Review (November 1968), p. $11-24$.

"ratrak deleetw and Joh Kalchbrener, "Monetary and Fiscal Actons: A Test of Their Relative Importance in Ecom nomic Stabilizaton - Comment, this Review (April 1969), mp. 6-11.

"25ee F. Gerald Corrigan, "The Measurement and Inportance of Fiscal Policy Changes," Federal Reserye Bank of New rork Monthly Review (June 1970), pp. 11345. More signiffcant, however, were probably the corroborative studien of Michael $W$. Keran. See his "Monetary and Fised Infuences on Economic Activity - The Historical Evidence," this Foview (Nowmber 1969 ), pp. $5-24$ and "Monetary and Fiscal Influences on Econonic Acturty: The Foreign Experience, this Revetw (Febrary 1970), pp. 1028 . The reader is also referred to Thomas 0 . Nitson, "A Furher Adjustment to a Test of the Relative Importance of Morsexary and Piscal Actions in Economis Stablization, "Nebraska Joumal of Economics and Busmess (Winter 1972), pp. $11-24$.

26Sec Meigs, Money Matters, Economics, Muskets, Polmics, for an expanded discussion. Also see michard $G$. Davis. "How Much Does Money Matter? A Look at Some Recent Evidence, "Federal Reserve Bank of New York Monthy Revien Une 1969), po. 119-31, and Edward M. Gram lich, "The Usefumess of Monetary and tiscal Policy as Discretonary Stabilization Tooks," Joumal of Money, Credi, and Banking (Nay 1971), pp. 506-32. 
The nature of the controversy has continued along these lines up to the present. There have been no periods since 1968 when monetary and fiscal actions have moved sharply and persistently in opposite directions, so direct tests of the relative potency of monetary and fiscal actions are generally mavailable from late 1969 to early $1973 .^{2 T}$

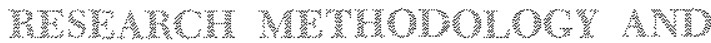

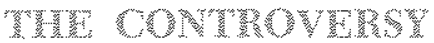

Over the last five years there has been considerable confusion as both monetarist and fiscalist factions have been guilty of distorting the opposing faction's model in order to make a point. For example, the discussion has run from "money doesn't matter vs. money matters" to "money matters vs. money only matters," and recently it has been suggested that the issue is really "fiscal matters vs. fiscal doesn't matter."

Associated with the development of the monetaristfiscalist controversy has been the question of appropriate research methodology. The evidence in support of monetarist propositions has been based in large measure on a reduced-form approach to the estimation and testing of statistical relationships between monetary and fiscal variables and economic activity. The fiscalist participants in the controversy, on the other hand, have relied on a structural model approach to the estimation and testing of relationships regarding the economic impact of policy variables. ${ }^{20}$ The purpose of this section is to discuss these methodological questions as they bear on the controversy.

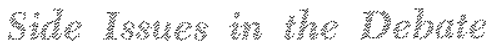

Several side issues have developed in the controversy over the Andersen-Jordan article. The A-J study

\footnotetext{
${ }^{27}$ Sprinkel, Money and Markets: A Monetarist View, pp. 1516. indicates there were two other episodes of cortrasting policy change in 1969 and 1970 , but these cases are not as clearcut as the episodes of 1966 and 1968.

28For discussion of "money" issues see Paul Samuelson, "The Role of Money in National Economic Policy," in Controlling Monetary Aggregates (Proceedings of the Monetary Conference Held on Nantucket Island, Sponsored by Federal Reserve Bank of Boston, June 8-10, 1969), pp. 7-13. For discussion of "Pscal" isstes, see Ronald L. Teigen, "Some Ohservations on Monetarist Analysis," Kredit und kapital, 3 (1971), pp. 243-63, and Warren L. Smith, "A YeoKeynesian View of Monetary Policy, in Controlling Monetary Aggregates, pp, 105-26, and Corrigan, "Measurement and Importance of Fiscal Policy Changes.

29 For a readable account of the distinction between statistical estimation and hypothesis testing, which seems to be a relevant issue underlying the reduced form vs. structural controversy, see R. L. Basmann, "The Role of the Economic Historian in Predictive Testing of Proffered 'Economic Laws," in Ralph L. Andreano, ed., The New Economio History: Recent Papers on Methodology (New York, John Wiley and Sons, 1970), pp. 17-42.
}

consisted of the formulation and testing of several macroeconomic propositions. These hypotheses involved various characteristics of the response of nominal GNP to monetary and fiscal actions. The test included direct estimation of equations with changes in GNP as the dependent variable and measures of monetary and fiscal actions as independent variables. This method of testing was called the reduced form approach.

Use of the term "reduced form" is unfortunate, becatuse the term has an alternative meaning in applied econometric analysis. To most of the profession, "reduced form" is automatically associated with a structural model that is, a set of equations serving as a representation of the behavior of the economic system. Commonly accepted procedure in macroeconometric analysis in 1968, and continuing to the present is to:

(1) Collect data and make point estimates of the parameters in the structural equations;

(2) Assume (a) the model is correct, (b) the background conditions are true, and (c) the point estimates of the structural parameters are the true values;

(3) Use data for the exogenous variables, outside of the sample period, and generate values for the endogenous variables;

(4) Compare forecasted values of the endogenous variables with actual values;

(5) Draw conclusions about the validity of the model on the basis of this comparison. ${ }^{30}$

The Andersen-Jordan study, on the other hand, did not follow commonly accepted procedure in applied econometrics. Their study reported the results of several tests of hypotheses concerning the characteristics of the response of GNP to monetary and fiscal actions. They did not test a particular model depicting the operation of the economic system. Their estimated equations were reduced forms in that they were relationships between one endogenous variable and a number of exogenous variables, but the form of these equations was not derived from an explicitly stated structural system.

\footnotetext{
30This method of evaluating an econometric model is called the "method of forecasting test." See James L. Murphy, "An Appraisal of Repeated Predictive Tests on an Econometric Model," Southern Economic Joumal (April 1969), pp. 293-307, and Introduciory Econometrics (Homewood, ill. Irwin, 1973). Basmann comments on the procedure as follows: "The tendency of policy-riented econometricians has been to fommulate models, to argue in a more or less Aristotelian fashion for the plansibility of the inderlying assumptions, and to trust to the efficacy of asymptotically efficient (viz., large-sample) methods of statistical estima tion to bing them somewhere near knowing the true values of economic parameters." [Basmann, "The Role of the Economic Historian," p. 161.]
} 
The nature of the A-I results caused considerable confusion. At the time, there were certain notions (or vague hypotheses) about the operation of the economic system that prevailed among macroeconomists. These notions were, of course, carryovers from the Friedman-Meiselman controversy earlier in the decade. The A-J results appeared to be consistent with the quantity theory and not consistent with the Keynesian theory. The "implications" of the Keynesian theory were that fiscal actions were more powerful than monetary actions, so the A.I results were viewed as a challenge to the existing Keynesiar orthodoxy.

In retrospect, this association of the A-I results with tentative acceptance or rejection of particular models, though probably inevitable, was also unfortunate. These results set off discussions which were not relevant to the issues at hand, namely, "How can we accept your results until we see your theory?"

To isolate the issues which are relevant, consider first the irrelevant isstes. One irrelevant issue is whether the A-J test is a test of a quantity theory vs. a Keynesian theory. Andersen and Jordan did not develop and test explanatory models of the mechanism describing the transmission of monetary and fiscal impulses to the economic system. The A-J tests yielded some interesting implications for the quantity vs. Keynesian theory question, but as presented, the A J article did not represent a direct test of these alternative theories.

A second irrelevant issue is whether structural or reduced forms are the appropriate methodology. The terms "structural form" and "reduced form" do not represent competing methodologies. If the model builder is interested in describing one possible system that is useful in forecasting and simulating economic experience, then a structural form may be most appropriate. On the other hand, if the model builder is interested in policy recommendations or evaluations, a theoretical interpretation of parameters is required. And such an interpretation requires the formulation and testing of hypotheses; an integral part of this procedure is the definition of regions of acceptance and rejection in terms of the reduced form parameters, $^{31}$

It is certainly true that the A.J study did not follow procedure that was commonly accepted at

31For extensive discussion of this alternative nethod of evaluating econometric models, which is called the "method of predictive testing," see Murphy, "Repeated Predictive "Tests on an Econometric Model ${ }^{\prime \prime}$ and the references to Basmam's other works cited therein. the time. But this point is fundamental: the A-J study reflected dissatisfaction with existing procedures in assessing the mpact of monetary and fiscal actions. Over the years, monetary and fiscal multim pliers, which were derived from models assumed to be true, had come to be accepted as approximations of reality. ${ }^{3: 2}$ The A-J propositions, simple as they were, were direct tests of alternative hypotheses about the response of the economic system to monetary and fiscal actions.

What issues relating to the A-I study are relevant? First, the statistical properties of the estimated equations used in the A-J study require close scrutiny. To a considerable extent this scrutinizing has been done by examining in detail the choice of combinations of monetary and iscal variables. ${ }^{39}$ Also, the "endogeneity of money" issue is relevant to the extent that a bias is present in the estimated coefficients. Though it should be pointed out that the question of money endogeneity has little to do with the formulation of the hypothesis about monetary infuence. ${ }^{34}$

A second issue that seems relevant to the discussion is an examination of the derived reduced form multipliers for the Keynesian models in light of the dim rectly estimated A-I multipliers. In other words, once the estimated A-J equations have been checked out for their statistical properties, it seems logical for the Keynesians to develop their systems in such a way that they could be tested as an interdependent unit, rather than accepting point estimates of structural parameters as a basis for calculating policy multipliers. Rigid attachment to this method of calculating policy multipliers has been a stumbling block to raising the level of discussion relating to the A-I results. ${ }^{35}$ The

"2For further discussion of this point, see Meigs, Money Mafters: Economics, Markets, politics, and John Deaver, "Monetary Model Building," Business' Economics, (September 1969 ), pp. 29-32.

"3s See dekeeuw and Kalchbremer, "Monetary and Fiscal Actions - Comment," Davis, "Wow Much Does Money Matter," and Comigan, "Measurement and Importance of Fiscal Policy Changes."

"-4 See Christopher A. Sims, "Money, Income, and Casuality", American Economic Review (September 1972), pp. 540-52: an interesting unpubished paper by $\mathrm{I}$. W. Elliott, "The Infuence of Monetary and Fiscal Actions on Total Spending: The St. Lous Model Re-visited" (December 1972), presents evidence supporting the notion that government spending is "endogenous" rather than money. For further discussion of enclogenous stabilization actions, see Stepher $M$. Goldfeld and Alan S. Blinder, "Some Implications of Endogenous Stabilization Policy," Brookings Papers on Economic Activity, $3(1972)$, pp. 585-640.

(asfor an example of the serious misuse and misinterpretation 3 f the A-T equation, the reader is referred to Franco Modigliani, "Monetary Policy and Consumption; Linkages via Interest Rate and Wealth Effects in the FMP Model," 
Keynesian model had been used so often and so long by macrocconomic analysts that it evolved into conventional wisdom withou being tested except on a piece-meal basis.

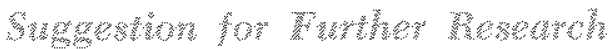

Given the confusion that has arisen in connection with the A-J study, as well as the resulting uphenval of enotions, what might represent an appropriate directon for future research? Oné possible effort. given the interest in the monetarist "black box," wond be for monetarists to develop and rest theories relating to the mechanism whereby monetary and fiscal impulses are transmitted to the economy. Such studies conld shed light on the meaning and significance of the monetarist propositions. ${ }^{36}$

The following list of steps as ontlined by Professor James Murphy could serve as a guide to testing the model, since the objective is to understand the modus operandi of the effect of monetary and fiscal artions rather than to replicate economic experience:

(1) Speciry the model in structural form and formulate postulates about ifs parameters;

(2) Derive the reduced fom parmeters as funotions of the struetural parameters;

(3) Derive the acceptance regton for the reduced form parmeters to satisty the identifability hypothesis;

(4) From the structural parameters and identif:ablity condition, derive the acceptance region for the model;

(5) Define the appropriate tests for acceptance or rejection, then obtain estimates of the reduced form parameters;

Constmer Spending and Monetary Policy: The Linkages (Proceedings of a Monetary Conference Held on Nantucket Island, Sponsored by Federal Reserve Bank of Boston, June 1971), wo pp. 59-74. Modigliani performs what he calls a Monte Carlo experiment (1) assuming that the solution values of the Federal Reserve-MTT-Penn (FMP) model are a true representation of the economio system, then (2) using these solution values as "data" and ruming an A f t type equation, The results of this experment are an $A-f$ equator of the ustal type, i.e. a money multiplier equal to about 6 and a fiscal multipler near zero Modiglianis intereretation of his experiment is that reducet forms are subject to the danger of severe bias. An alternative interpretation is that the experiment demonstrates anly hat the FMP model is a "goud" foreensting model, capable of generating simulated values very close to actal values. Undt the FMP nodel is tested and contrmed as an explanatory economic model, such expetiments carry little meaning.

Wh example of an efort in this ate of Some Monetarist Propositions." Though Pasche has not tested his model, he has developed hypotheses about economic behavior which appear to provide a basis for further investigetion of monetarist propostions. See also an nopub. hished paper by Ronald I. Sutherland "On The Effectiveness of Monetary and Fiscal Actons" November 1973 ).
(6) Determine whether the relewant background conditions hold, and accept or reject the model $3:$

This stands as an ambitious list, and is, of course, much easier said than done. Attempted use of this method of predictive testing of altematve models cond shed considerable light on the monetaristfiscalist controversy, especially as it relates to the transmission mechanism.

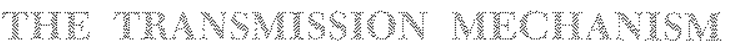

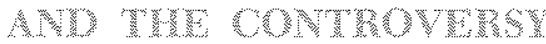

One of the more interesting issues relating to the monetarist-iscalist controversy is the assumed nature of the transmission mechanism. Even though Brunner lists the transmission mechanism as a separate issue in macroeconomics, it seems that the transmission issue is in a focal position so far as the controversy is conn cerned. Clarification of the assumed nature of the transmission mechanism can provide a better understanding of the other macroeconomic issues, in particular, the dominat mpulse and aggregative vs. allocative issues.

\section{Whang}

The Hicksian IS-LM model is the fundamental expository framework for virtually everyone who works and teaches in the field of macroeconomics. ${ }^{28}$ A basic characteristic of this model is that the chamels of monetary infuence are restricted to interest rates and wealth. The primary channel of infuence for fiscal actons, on the other hand, is via a direct effect on income. The IS-LM model is seldom used in its simplest form, but it does serve as a core model that helps to maintain order among the thought processes of the investigator. Its simplicity, as well as adaptability to a large number of problems, has accomted for its almost universal acceptance. Continued use of the IS-LM analysis in a form almost identical to that published in 1937 attests to its durability as a tool of macroeconomic analysis.

Attacks on the IS-IM model have been few and far between over the past 30 years. What is even more

3i Murphy, "Repeated Predictive Tests on an Fconometric Model also notes that if the model contans lagged endogenous variables, dyamic stablity conditions are also a part of step (4).

38T. R. Hicks, "Mr. Keynes and the 'Classics': A Suggested interpretation," Econometrica, vol, 5 (1937), po. $147-59$. See also Karl Brmner and Allan $\mathrm{H}$. Mektzer, "Mr. Hicks and the "Monetarists," Fconomion (Febreary 1973), pp. $44-59$. 
surprising is that the IS-LM model has not been tested as a unified set of hypotheses. This is not to say that individual relations embodied in the model have not been tested and estimated, but this procedure is a far different matter than applying the BasmannMurphy method of predictive testing.

One critique of the IS-LM analysis is found in a comment by Professor David Meiseman at the first Federal Reserve Bank of Boston Monetary Conference in 1969.3 Meiselman raises the following questions:

(1) Are IS and LM curves independent of each other?

(2) Is the IS curve negatively or positively sloped?

(3) How are price expectations effects taken into account in the IS-LM analysis?

Meiselman's criticisms apply to the IS-LM analysis as traditionally used. As a theoretical construct, the Hicksian model is not criticized. Rather, Meiselman tends to level his attack on users of the model, not on the model itself.

In summary, it appears that the Hicksian IS-LM model provides a convenient starting point for analyzing macroeconomic problems, even if it has never been subjected to predictive tests. If it is found that the traditional use and interpretation of the model leads to incorrect conclusions with respect to the formulation and implementation of stablization policy, then there is good reason to question the usefulness and validity of the model in its simplest form. Unfortunately, it is difficult to point to a particular piece of published work that gets specific and forms a policy recommendation on the basis of the Hicksian model. This model almost always seems to be invoked after the fact. ${ }^{40}$ One would think if a model is so universally applicable in ex post explanation, it would be used more widely as a predictive tool.

\footnotetext{
39David Meiselman, "Discussion," in Controlling Monetary Aggregates (Proceedings of the Monetary Conference Held on Nantucket Island, Sponsored by the Federal Reserve Bank of Boston, June 8-10, 1969), pp. 145-51, Milton Friedman was also critical of some aspects of the IS-L.M analysis in "Interest Rates and the Demand for Money," Joumal of Law and Economics, (October 1966). pp. 71-85. There are, no doubt, other critiques, but the fact so few come to mind suggests that such critiques have been rare over the last 36 years.

40For example, Teigen, in "A Critical Look" pp. 19-20, argutes that observed parallel movements between money and in terest rates are quite consistent with the basic IS-1.M stmcture. This is very common procedure: manipulating the IS-LM model in such a way as to explain economic events after they happen. More often than not, these "explanations" are not logical implications of the model itself.
}

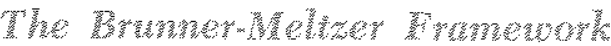

For a number of years Professors Brunner and Meltzer have been critical of the traditional usage of the IS-LM model. The general nature of their objecthons is contained in their comment on Friedman's theoretical framework. ${ }^{41}$ These objections are given more specifically in their presentation of an alternative Framework." In this attcle, Brunner and Meltzer develop a model that they propose as an alternative to the IS-LM framework.

The deficiencies of the IS-LM framework, according to Brumer and Meltzer, are as follows: ${ }^{43}$

(1) Bonds and real capital are treated as a single asset. Money substitutes only for bonds, not for existing assets or output.

(2) The theory has not been successfully confirmed.

(3) The only simultaneous solution for the price level and real output is the full-employment solum tion. The problem of persistent unemploymen? is not explained.

Brumer and Meltzer's objective in their article was to correct two of these three deficiencies, omitting consideration of $(2)$.

Before examining Brumner and Meltzer's effort to correct these deficiencies, consider the possible reaction to this short list of deficiencies. Not enough time has passed for comments on the Brumer-Meltzer: paper to appear, but it is not diffeult to formulate a possivie reaction to their characterization of the "standard model."

(1) True, the original Hicksian article focused on money-bond substitution, but the work of Professor Tobin represents an important extension of the Hicksian model to include substitution between money and real capital. ${ }^{41}$

11Karl Brunner and Allan H. Meltzer, "Friedman's Monetary "Theory" Jotwnal of Political Economy (September/October 1972), pp. 837-51. See also their "Mr. Hicks and the "Monetarists."

"'Kar" Brmner and Allan Meltzer, "Money, Debt, and Economie Activity," Joumal of Political Economy (September/ October 1972 ), pp. 951-77. The work of Brumer and Melzzer relating to this altemative framework goes back many years. An early ciscussion of his framework, though not the first, is ${ }^{2}$ The Place of Finandial Internediaries in the Transmission of Monetary Policy," American Economic Review, Papers and Proceedings (May 1903), pp. 372-82.

43A comparison of this list with the first two pages of their article, "Money, Debt, and Economic Activity" indicates a difference in the listing, In their article, deficiency (3) is listed under (1), and their thitd deficiency is that standard macro theory has not incorporated developments in monetary and price theory of the past two decades.

4 See the relevant articles in fames Tobin, Fissays in Mocroeconomics, Volume I (Chicago: Markhan, 1972). 
(2) This statement is not true because currently existing econometric models are essentially com plex and detailed extensions of the IS-LM framework, and these models have proven successful.

(3) The inability of the IS-LM model to explain persistent unemployment is well-known. This model has long since been extended to determine the price level, output, and employment. "Extended" models, permitting determination of prices and output have become standard material in macroeconomic textbooks.

It is not hard to imagine the barrage of charges and countercharges that could be set in motion if this type of rejoinder appeared. And in the process, the significance of the Brunner-Meltzer contribution could easily be lost in the smoke of the argument.

The purpose of this section of the paper is to clarify a fundamental difference between the IS-LM model and the alternative framework developed by Brunner and Meltzer. First, the question of whether the IS-LM model has been confirmed is set aside in an effort to focus on the differences in specification of the two models. Second, the problem of output and employment determination is set aside for expository purposes. This procedure simplifies the problem by focusing on the differences between the two models as they relate to the determination of the demand for output at a given price level. To ignore these issues is not to say that they are unimportant; there should be general agreement to the contrary.

By the process of elimination we are left with the deficiency relating to the assumption of substitution between only money and bonds. The interpretation offered here is that this assumption is a key one differentiating the aggregate demand portion of the Brunner-Meltzer framework from the "traditional" IS-LM model. ${ }^{45}$

Why are Brunner and Meltzer so concerned with the money-bonds substitution assumption? The answer is that this assumption implies that the transmission mechanism from money to economic activity is limited to interest rates. The IS-LM model may be amended to include wealth effects, but the moneybonds substitution assumption places emphasis on a borrowing cost mechanism for transmitting monetary

\footnotetext{
4 The adiective "traditional" is used here to be representative of that class of IS-LM models which is used in macroeconomic textbooks. With very few exeeptions, textbook IS-LM models buld in the assumption of "money and bonds only" substitution. Furthermore, with the exception of Tobin, recent published articles by neo-Keynesians continue to give little emphasis to this assumption. See, for example, Teigen, "A Critical Look."
}

impulses. More generally, in an attempt to represent the essence of the operation of the economic system, limiting a model to only one relative price - the interest rate $-i s$ considered far too restrictive. The logical implications for the effects of monetary and fiscal actions, as well as other factors, are seriously limited if such impulses are permitted to be channeled to economic activity through the movement of only one relative price - the interest rate.

The procedure followed by Brunner and Meltzer to correct the "money-bonds" deficiency in the IS-LM model is to add a market for existing assets, or what they call the market for "existing real capital," By adding such a market, another relative price is added to the IS-LM model, broadening substantially its capabilities for testing hypotheses about the effects of monetary and fiscal actions and other exogenous impulses. ${ }^{46}$

By excluding the price of existing real capital, the traditional IS-LM model must either assume (1) that there is a perfect capital market whereby the price of existing real capital is always equal to the price of new production, or (2) that there is no market for existing capital. ${ }^{47}$ The first assumption is a property of classical economic models where all costs of information and adjustment vanish, and defines what is generally known as long-run equilibrium. The second assumption, on the other hand, is more typical of Keynesian models.

By adding a market for existing real capital to the IS-LM model, the price relevant to that market is added to the list of variables that are potential arguments in each of the behavioral equations of the model. But the effect is much more significant than just adding another variable. One benefit is that the model can then be written in such a way as to separate the market for money from the market for

\footnotetext{
4the question may naturally arise as to how this price is measured, and measurement problems have no doubt beer a factor underlying the neglect of this variable in macroeconomic analysis. in principle, suen problems should be little greater than measuring "the price" applicable to new prow duction. The development of the national income accounts to the neglect of balance shees considerations has no doubt contributed to the development of theory in the direction of focusing on new production and its related price. Bat lack of data on the price of existing capital loes not negate its role in the transmission mechanism. For a recent discussion of prices ard price indices, see Amen A. Alchian and Bengamin Klein, "On a Correct Measure of Inflation," Journal of Money, Credit and Banking (Febuary 1973), pp. 173-91.

tiSee the unpublished paper, Kart Brunner and Altan $H$ Meltzer, "The Inflation Problem" (March 1973), for discus-
} sion of this point. 
credit. ${ }^{48}$ In the opinion of Brunner and Meltzer, the relative role of these two markets has been one of the chief contributing factors to the confusion surrounding the monetarist - neo-Keynesian controversy. ${ }^{49}$ And it is this separation that leads to logical implications which differ substantially from those derived from the traditional IS-LM analysis.

In the traditional IS-LM analysis, the credit market is the hidden, or "left-out" market. Or in Patinkin's work it is the bond market. ${ }^{50}$ On occasion, failure to examine the implied credit market has resulted in the development of some very peculiar conditions which do not become obvious until the hidden market is explicitly derived. ${ }^{51}$

Brumner and Meltzer do not question the existence of the hidden credit market; rather, they are concerned with the limited nature of the transmission mechanism whereby monetary and fiscal actions affect economic activity in traditional IS-LM models. Every multimarket model has at least one redundant market, as long as Walras' law of markets is accepted. Brunner and Meltzer, after adding an additional asset - existing real capital - retain the option of maintaining the credit market as the redundant market. However, they choose to make the credit and money markets explicit, making the market for existing real capital the redundant market. With this choice they are able to examine thoroughy the factors which contribute to the nature of economic response to monetary and fiscal actions.

By examining the expanded model, the deficiencies implicit in the use of the traditional IS-LM model become apparent. Very generally, Brumer and Meltzer conclude that the effect of monetary and fiscal actions, as well as other exogenous impulses, depends on the price of existing real capital as well as the interest rate and the price of new production. (Recall

48It should be pointed out, however, that the term "money market" is a misnomer. II a money economy money is traded in every market; there is no "market" for money. For further discussion, see R. W. Clower, "A Reconsideration of the Microfoundations of Monetary Theory," Westem Economic Journal (December 1967), pp. 1-8.

49For a comprehensive discussion of this essential distinction, see Albert E. Butger, The Money Supply Process (Belmont, California: Wadsworth Publishing Conpany, Inc., 1971),

50Don Patinkin, Money, Interest, and Prices, second edition (New York: Harper and Row, 1965).

51Carl Christ, "Monetary and Fiscal Policy in Macroeconomio Models," in The Economic Outlook for 1969 (Papers presented to the Sixteenth Annual Conference on the Economic Outlook at the University of Michigan, November 14-15, 1968), pp. 93-112, and Bent Hansen, A Survey of Generd Equilibritm Systems (New York: McGraw Hill Book Company, 1970), esp. pp. 134-37. that throughout this discussion the price of new production has been treated as a given, and its determination requires further extension of the model, This extension, of course, is provided by Brumner and Meltzer.) What is implied is that the nature of the response of the economy to monetary, fiscal, and other stimuli is conditioned by an enlarged number of considerations.

More specifically, the Brunner and Meltzer conclusions, as they relate to the aggregate demand portion of their model, can be summarized as follows:

(1) The interest elasticities (or slopes) of the traditional IS and LM curves are neither necessary nor sufficient for determining the response of aggregate demand for output (at a given price level for such output) to monetary and fiscal actions.

(2) The role of weatth or real balance effects in macroeconomic models is substantially changed when a market for existing real capital is introduced. In particular, the response of aggregate demand to monetary impulses need not depend on wealth effects (or interest elasticities of IS and $/$ or LM).

(3) A maintained government deficit financed by issuing debt rases interest rates and the price of existing real capital. Consequently, fiscal multipliers are conditioned by considerations other than interest elasticities and wealth effects.

This is a partial restatement of Brumer-Meltzer's own summary. Their conclusions are more far-reaching than the above summary suggests. But the nature of these statements is interesting in that their conclusions, for the most part, list those factors that are relevant in testing hypotheses. For example, virtually all of the macroeconomic textbooks characterize the monetarist model as the "extreme" case where the interest elasticity of money demand is zero, for this is the only way to get a fiscal multiplier of zero. Acceptance of such a characterization of the monetarist model implies that the statistical significance of the interest elasticity of money demand becomes the crucial test of the monetarist model (at least with respect to its implications for fiscal policy). If this elasticity is not significantly different from zero, the hypothesis as it relates to fiscal impact has to be rejected. Brunner and Meltzer, in contrast, show that a zero interest elasticity of money is not necessary in order that the fiscal multiplier be zero.

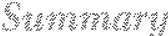

The Brumer-Meltzer macroeconomic framework has been discussed at some length, but certainly not in detail, and contrasted with the traditional IS-LM 
analysis. However, it should be emphasized that only the short-run aggregate demand aspect of the Brumner-Meltzer model has been discussed here. This focus is very limited, for they have devoted substantial effort to delineating price and quantity adjustments in the output market and to longer-run considerations. As indicated earlier, such considerations are ignored here, but in no way is this meant to denigrate their importance.

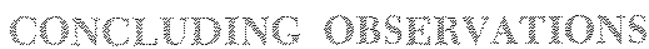

The focus of this paper is on recent macroeconomic controversy. A brief review of economic events and economic thinking in the period since World War II serves as background for elaboration of the nature of the controversy as it presently exists. A general observation developing out of this review is that particular economic events or experiences do have a substantial impact on the development of economic thought. A likely consequence of this immediacy of response to recent experience is that the profession can be misled for a considerable period of time. At all times the experience of economic history should be kept clearly in perspective. ${ }^{22}$ It is in this connection that the extensive work by Friedman and Schwartz serves as a significant contribution to macroeconomics relative to that of econometric studies based on only 15 or 20 years of data However, studies with a long historical perspective tend to be ignored by policymakers who are preoccupied with solving short-run problems of economic stabilization. ${ }^{54}$ Apparent lack of im-

52For an example of perspective on the relation between money and prices covering the period from 500 B.C. to the early 1930s, see Ama I. Sehwartz, "Secular Price Change in Tistorioal Perspective," Journal of Money, Credit and Banking (Febrary 1973), pp. 243-69.

53 Milton Friedman and Ama Jacobson Schwartz. A Monetary History of the United States: 1867-1960 (Pinceton: Prince ton University Press, 1963 ).

satete the following statement by Frizz Machlup in Emil Clasen and Pascal Salin, eds., Stebilization Policies in Inter. dependent Economics (Proceedings of a conference held at the University of Paris-Dauphne, March 1972), p. 34: mediate relevance does not negate the operation of longer-run principles.

The second part of this paper identified those factors which appear relevant to the present controversy on the relative impact of monetary and fiscal actions. Several side issues were shown not to be directly relevant to the issues at hand. A gap has developed between monetarists and fiscalists that has tended to impede rather than advance the level of understanding relating to the role of monetary and fiscal actions.

It was concluded that methodological issues have been confused with the hypotheses. Specifically, questions of "reduced forms vs. structure" have sidetracked the discussion as well as introduced confusion as to just what a hypothesis is. Tracing the source of confusion to one side or the other is difficult and not particularly useful. It is probably to be expected that the advance of knowledge is almost always accompanied by confusion as the conventional wisdom comes under attack. ${ }^{53}$

In an attempt to clarify the issues, the final section of the paper discussed a portion of an alternative framework for macroeconomic analysis. This framework has been developed by Professors Brunner and Meltzer, and stands in contrast to the traditional IS-LM model. A market for existing real capital is explicitly incorporated in the Brunner-Meltzer model and the stabilization implications of monetary and fiscal actions are shown to be substantially broader than those of the IS-LM model.

"While we are on the distinction between the short ran and the long, I may be allowed to comment on the famous dietum by Keynes to the effect that we always live in the short run, and in the long run we'll all be dead. My counterdictum is that the short run is awfully short and before long well all be terribly sick. This does not mean that we should forget about the shork run, but it does mean that serions economics should deal chiefly with the longurun consequences of our public policy actions."

55 This statement is not attributable to Harry Johnson, but the reader is referred to Harry $G$. Johnson, "The Keyne; stan Revolution and the Monetarist Counter-Revolution," American Economic Review, Papers and Proceedings (May 1971), pp. 1-14.

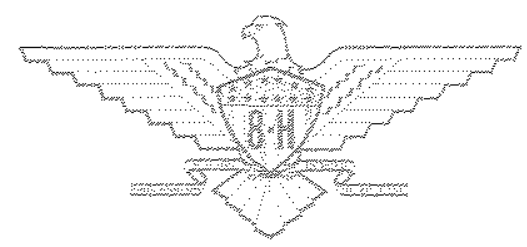

